\title{
Search for retroviral sequences in peripheral blood mononuclear cells and brain tissue of multiple sclerosis patients
}

\author{
R.Jocher', A.Rethwilm ${ }^{1}$, L. Kappos ${ }^{2}$, and V. ter Meulen' \\ 'Institut für Virologie und Imınunbiologie, Versbacher Strasse 7, and ${ }^{2}$ Max-Planck-Gesellschaft, \\ Klinische Forschungsgruppe für Multiple Sklerose, Universität Würzburg. D-8700 Würzburg, Federal Republic of Germany
}

Recejved June 16, 1990/ Accepted July 4. 1990

Summary. DNAs from peripheral blood mononuclear cells (PBMCs) of 21 patients with multiple sclerosis (MS), 1 patient with tropical spastic paraparesis (TSP) as well as DNAs from brain and spinal cord of 5 MS cases and 3 controls were examined for human $\mathrm{T}$-cell lymphotropic virus (HTLV)-related sequences by polymerase chain reaction. The primers used were derived from the HTLV-I gag, env and tax genes. Amplified products were separated on agarose gels, blotted onto nylon membranes and hybridized to specific radiolabelled oligonucleotides. The sensitivity of amplification and hybridization was one copy of target DNA in $10^{5}$ cellular genomes. None of the specimens was positive for HTLV-I sequences except the TSP probe. These negative data are all the more significant because brain material from MS patients was used in these studies. Our studies thus fail to support speculations that HTLV-I is involved in the aetiology of multiple sclerosis.

Key words: Multiple sclerosis - HTLV-I - Polymerase chain reaction

\section{Introduction}

Multiple sclerosis (MS) is a remitting and relapsing demyelinating disease whose aetiology is still unknown. Epidemiological data and virus-included MS-like diseases in laboratory animals are suggestive of a viral infection in MS [26]. In particular, the association of human immunodeficiency virus (HIV) in AIDS encephalopathy and human T-cell lymphotropic virus I (HTLVI) in tropical spastic paraparesis (TSP) has given support to the hypothesis that human retroviruses may also be involved in MS. Moreover, following serological and in situ hybridization studies a possible relationship between HTLV-I related viruses and MS has been suggested [8, 13]. However, other investigators obtained negative results and could not confirm this association $[5,7]$.

Offprint requests to: V. ter Meulen
More recently the polymerase chain reaction (PCR) has been applied to search for retroviral sequences in MS, taking advantage of this technique to detect minute amounts of a certain nucleic acid [20]. Reddy et al. [18] reported the amplification of HTLV-I gag and env sequences from macrophages in 6 Swedish MS patients, while 19 out of 20 control samples remained negative. Greenberg et al. [3] found HTLV-I pol sequences in 6 of 21 MS patients; 3 of these were also positive for HTLV-I env, whereas 35 controls remained negative. In contrast, Bangham et al. [1], Richardson et al. [19], and Nishimura et al. [12] failed to detect HTLV-I sequences in a total of $76 \mathrm{MS}$ patients. Furthermore, Fugger et al. [2] could not confirm the results of Reddy et al. [18] re-examining the 6 Swedish MS patients.

Since human retroviruses infect the central nervous system (CNS) and cause lesions as shown in AIDS encephalopathy or probably also in TSP, we have studied DNA extracted from 5 MS brains as well as from peripheral blood mononuclear cells (PBMCs) and peripheral macrophages from 21 MS patients, for the presence of HTLV-I sequences to find out whether MS brains may harbour HTLV-I or related sequences. We applied PCR using primers of HTLV-I gag and env genes as well as from the tax gene, since the latter gene is highly conserved among human retroviruses [11]. Except for positive controls, we failed to obtain a positive hybridization signal in any of our test samples. This indicated that the genome of HTLV-I or a related virus is not present in the DNA of mononuclear cells or brain from patients with MS.

\section{Subjects and methods}

\section{Patients and DNA extraction}

The data of the patients are summarized in Table 1. All patients had clinically definite MS according to the criteria of Poser et al. [16]. Ten normal control persons were matched for sex and age. Blood samples were coded so that the laboratory personnel performing DNA extraction and PCR had no knowledge of the iden- 
tity of the samples. PBMCs were prepared from heparinized blood by Ficoll-Hypaque gradient centrifuging [4]. Half of the sample was used to extract DNA directly, while from the second half adherent cells consisting of monocytes/macrophages were prepared as described [18], and were subsequently used to extract DNA. The extraction of DNA from cells and deep-frozen $\left(-80^{\circ} \mathrm{C}\right)$ brain tissue followed established procedures [10]. Brain specimens were derived from 5 MS cases, 2 of these with a short clinical course, 6 months and 1 year. From each MS brain samples were taken from the centre and periphery of several plaques as well as from areas histologically unaffected. In addition, 3 control brains were included, representing brain material from patients dying as a result of heart failure, brain tumour and amyotrophic lateral sclerosis (ALS). From the latter patient spinal cord material was also

Table 1. Clinical data of the multiple sclerosis patients studied

\begin{tabular}{rllrll}
\hline No. & Sex & $\begin{array}{l}\text { Age } \\
\text { (years) }\end{array}$ & $\begin{array}{l}\text { Duration } \\
\text { of disease } \\
\text { (years) }\end{array}$ & EDSS & $\begin{array}{l}\text { Course } \\
\text { of } \\
\text { disease }\end{array}$ \\
\hline 1 & F & 40 & 1 & 2.0 & 2 \\
2 & M & 28 & 3 & 3.0 & 2 \\
3 & F & 29 & 7 & 1.5 & 1 \\
4 & F & 34 & 9 & 6.5 & 3 \\
5 & M & 51 & 21 & 2.5 & 2 \\
6 & M & 31 & 9 & 3.5 & 3 \\
7 & F & 35 & 17 & 6.5 & 4 \\
8 & F & 39 & 4 & 3.0 & 2 \\
9 & F & 50 & 17 & 1.5 & 1 \\
10 & F & 48 & 7 & 4.0 & 3 \\
11 & M & 34 & 5 & 1.5 & 1 \\
12 & F & 41 & 9 & 1.5 & 1 \\
13 & M & 49 & 3 & 2.5 & 2 \\
14 & F & 47 & 11 & 3.5 & 4 \\
15 & F & 45 & 2 & 2.0 & 2 \\
16 & F & 52 & 10 & 6.5 & 3 \\
17 & F & 53 & 33 & 6.5 & 4 \\
18 & M & 25 & 2 & 2.0 & 2 \\
19 & M & 45 & 2 & 1.0 & 1 \\
20 & M & 51 & 11 & 6.0 & 4 \\
21 & M & 53 & 5 & 3.5 & 4 \\
\hline
\end{tabular}

axpanded disability status scale [9]

b 1 , Relapsing with complete remissions; 2 , relapsing with incomplete remission; 3 , relapsing-progressive; 4 , secondary chronic progressive tested. TSP DNA was kindly provided by Dr.S. Nightingale (Birmingham, UK) and Dr.C. Bangham (Oxford, UK). MT-2 cell line [27] containing several HTLV-I genomes was obtained from Dr.B.Zorr (Berlin) and the HTLV-I tax gene carrying plasmid pKCR42 [6] from Dr.M. Hatanaka (Kyoto, Japan).

\section{Primers and probes}

The primers and probes used for PCR analysis are summarized in Table 2. gag and env primers are the same as those published by Reddy et al [18]. tax primers and probe are more than $80 \%$ homologous to the HTLV-II sequence [23]. All oligonucleotides were synthesized using phosphoramidite chemistry on a Cyclone DNA synthesizer (Milligen, Eschborn, FRG) and purified by polyacrylamide gel electrophoresis.

\section{$P C R$ analysis}

Amplification was carried out with $1 \mu \mathrm{g}$ or $2 \mu \mathrm{g}$ DNA in a reaction volume containing $16.6 \mathrm{mM}\left(\mathrm{NH}_{4}\right){ }_{2} \mathrm{SO}_{4}, 67 \mathrm{mM}$ TRIS (pH 8.8), $6.7 \mathrm{mM} \mathrm{MgCl} 2,100 \mu \mathrm{g} / \mathrm{ml}$ bovine serum albumin (BSA), $10 \mathrm{mM}$ mercaptoethanol, $0.2 \mathrm{mM}$ of each dNTP (Pharmacia, Uppsala, Sweden), $1 \mu M$ of each oligonucleotide primer, and 1.25 units Taq DNA polymerase (New England Biolabs, Schwalbach, FRG). After an initial denaturation step 40 cycles were run in a thermal cycler (Biomed, Theres, FRG) as follows: $1 \mathrm{~min} 60^{\circ} \mathrm{C}, 2 \mathrm{~min} 71^{\circ} \mathrm{C}, 1 \mathrm{~min}$ $94^{\circ} \mathrm{C}$. One-fifth of each reaction was subjected to agarose gel electrophoresis and transferred on to nylon filters (Gene screen plus, Du Pont, Dreieich, FRG) by alkaline transfer. Filters were prehybridized in $6 \times \mathrm{SSPE}$ [ $1 \times \mathrm{SSPE}$ is $0.18 \mathrm{M} \mathrm{NaCl}, 10 \mathrm{mM} \mathrm{NaH}_{2} \mathrm{PO}_{4}$ $\mathrm{Na}_{2} \mathrm{HPO}_{4}$ (pH 7.7), $1 \mathrm{~m} M$ ethylenediaminetetra-acetate (EDTA), $10 \times$ BFP $(1 \times$ BFP is $0.2 \mathrm{~g} / 1 \mathrm{BSA}, 0.2 \mathrm{~g} / \mathrm{l}$ Ficoll $400,0.2 \mathrm{~g} / \mathrm{l}$ polyvinylpyrrolidine), $0.07 \mathrm{~g} / 1$ tRNA and $1 \%$ sodium dodecyl sulphate (SDS) at $42^{\circ} \mathrm{C}$ for $3 \mathrm{~h}$. Hybridization was carried out overnight at $63^{\circ} \mathrm{C}-73^{\circ} \mathrm{C}$ (depending on the melting temperature of the oligo probe) in a fresh buffer containing $6 \times$ SSPE, $1 \%$ SDS and 1-4 $\times$ $10^{6} \mathrm{cpm} / \mathrm{ml}{ }^{32} \mathrm{P}$-end labelled oligo probe. Filters were washed twice in $6 \times \mathrm{SSPE}, 1 \% \mathrm{SDS}$ at room temperature $(10 \mathrm{~min})$, once in $1 \times$ SSPE, $1 \%$ SDS at the hybridization temperature $(1 \mathrm{~min})$ and $\mathrm{ex}$ posed to $\mathrm{Du}$ Pont Cronex films at $-70^{\circ} \mathrm{C}$ with an intensifying screen. Labelling of oligonucleotides with $\gamma^{32}$ P-ATP (Amersham, Braunschweig, FRG) and T4 polynucleotide kinase (Boehringer, Mannheim, FRG) was carried out as described previously [10].

\section{Results}

Crucial for the detection of minute amounts of a certain DNA sequence is the sensitivity of the PCR. In the case of gag and env primers the amplification efficiency was

Table 2. Oligonucleotide primers used for HTLV-I polymerase chain reaction

\begin{tabular}{|c|c|c|c|}
\hline Oligo & Function & Location [21] & Sequence $\left(5^{\prime}-3^{\prime}\right)$ \\
\hline gag 1 & Primer $(+)$ & $841-864$ & CGACCGCCCCGGGGGCTGGCCGCT \\
\hline 2 & Primer $(-)$ & $1375-1353$ & GGTACTGCAGGAGGTCTTGGAGG \\
\hline 3 & Probe & $1080-1101$ & GATCCCGTCCCGTCCCGCGCCA \\
\hline env 4 & $\begin{array}{l}\text { Primer }(+) \\
\text { Primer }(-)\end{array}$ & $\begin{array}{l}5662-5685 \\
6129-6106\end{array}$ & $\begin{array}{l}\text { CTCCCTTCTAGTCGACGCTCCAGG } \\
\text { GCCACCGGTACCGCTCGGCGGGAG }\end{array}$ \\
\hline 6 & Probe & $5877-5897$ & GCCTCTCCACTTGGCACGTCC \\
\hline $\operatorname{tax} 7$ & Primer $(+)$ & $7358-7377$ & GGAGACTGTGTACAAGGCGA \\
\hline 8 & Primer (-) & $7516-7496$ & AGGGATAAGGAACTGTAGAGC \\
\hline 9 & Probe & $7447-7468$ & AGAGCATCAGATCACCTGGGAC \\
\hline
\end{tabular}




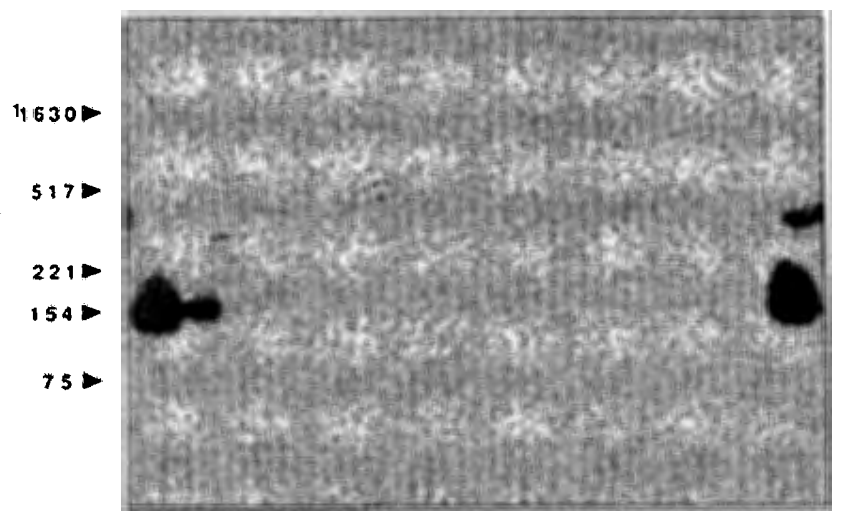

Fig.1. Polymerase chain reaction with HTLV-I - tax primers and brain tissue from MS patients and controls. tax primers yield a 159 bp fragment. Lanes $1-3: 300,30,3$ copies of tax target DNA each diluted in $1 \mu \mathrm{g}$ HTLV-negative control DNA; lane 4: HTLVnegative control DNA; lane 5: reaction without any DNA; lanes 7$9,11,12$ : DNAs from inflammatory plaques fo 5 multiple sclerosis brains; lanes $6,10,13$ : DNAs from control brains; lane 14: tropical spastic paraporesis DNA

determined by amplifying serial tenfold dilution of MT-2 cell DNA, which harbours approximately $10 \mathrm{HTLV}-\mathrm{I}$ genomes/infected cell. In our assay, one copy of MT-2 DNA was constantly detected in $10^{5}$ copies of uninfected cellular genomes with env-specific primers, while with gag-specific primers only one copy of MT-2 DNA was demonstrable in $10^{3}$ copies of cellular genomes. The sensitivity of tax primers was measured using the plasmid pKCR 42, revealing one target copy in $10^{5}-10^{6}$ copies of uninfected genomes (Fig. 1). Thus, amplification efficiency with env and tax primers was comparable to published studies applying PCR technology, while the efficiency of gag primers was poor. By applying the PCR to our MS and control specimens, none of the DNA derived from blood samples reacted positively with gag and env or tax primers, except the TSP DNA. Moreover, all brain-tissue-derived DNAs were negative with either primer pair tested (Fig. 1).

\section{Discussion}

The recent reports from two laboratories [3, 17], that sequences of HTLV-I are present in DNA of patients with MS have led to a resurgence of interest in the possible viral aetiology of MS. In this context, studies were carried out to confirm the association between HTLV-I and MS and also to find out whether other retroviruses may be associated with this disease. Using the PCR technique, we failed to detect HTLV-I sequences in DNA of mononuclear cells from $21 \mathrm{MS}$ patients. These negative data agree with findings from four other laboratories [1, $2,12,19]$. Negative PCR findings in the past have been explained by the proponents of the HTLV-I theory as lacking in sensitivity [17]. However, the sensitivity of the env and tax primers in our study was in the range of other studies employing PCR technology [20]. This holds true especially for the tax primers that were able to detect one copy of target DNA from a highly conserved region in up to $10^{6}$ cellular genomes. Thus, a lack in sensitivity is unlikely to be the reason for the failure to detect HTLV-I sequences in our MS and control probes studied.

To search for HTLV-I-related viruses in MS material we included primers from the tax gene of HTLV-I in our analysis. The tax gene was chosen because it is crucial for HTLV-I replication, since it encodes for the transacting activity [24]. In general, transactivating genes are highly conserved among retroviruses [11]. Therefore, using primers from the tax gene should allow the detection not only of HTLV-I sequences, but also of other related exogenous retroviruses.

In contrast to other groups searching for HTLV sequences in MS, we also analysed DNA extracted from MS brain tissue of five MS patients, since in other retrovirus infections with a neurological symptomatology viral footprints are detectable in CNS tissue. In murine leukaemia [14] or visna [25] virus infection of the CNS virus can be found in brain tissue. Similar observations have been made in HIV infection where viral DNA can be detected in brain material by Southern blotting [22] or PCR [15]. If in MS HTLV-I infection occurs in PMBCs one may expect viral sequences also to be detectable in inflammatory lesions in the CNS of MS patients, but the PCR results were also negative, indicating that HTLV-I or related virus was not associated with these cases.

Our data suggest that HTLV-I is not commonly found in patients with definite MS either in peripheral blood mononucleocytes or in brain tissue. However, we cannot exclude the possibility that a distantly related retrovirus or some other infectious agent that cannot be detected with our primer pairs may still be involved in the pathogenesis of MS.

Acknowledgements. We thank Dr.S. Siddell and T. Holtschke for oligonucleotide synthesis, B. Geyer for help with photography, and $\mathrm{H}$. Kriesinger for typing the manuscript. This work was supported by grants from the Bundesministerium für Forschung und Technologie and Hertie-Stiftung.

\section{References}

1. Bangham C, Nightingale S, Cruickshank JK, Daenke S (1989) PCR analysis of DNA from multiple sclerosis patients for the presence of HTLV-I. Science 246:821

2. Fugger L, Morling N, Ryder LP, Sandberg-Wollheim M, Svejgaard A (1990) Failure to demonstrate HTLV-I in multiple sclerosis patients. J Gen Virol 71:1103-1107

3. Greenberg SJ, Ehrlich GD, Abbott MA, Hurwitz BJ, Waldmann TA, Poiesz BJ (1989) Detection of sequences homologous to human retroviral DNA in multiple sclerosis by gene amplification. Proc Natl Acad Sci USA 86:2878-2882

4. Harris R, Ukaejito EO (1969) Rapid preparation of lymphocytes for tissue-typing. Lancet II : 327

5. Hauser SL, Aubert C, Burks JS, Kerr C, Lyon-Caen O, The G de, Brahic M (1986) Analysis of human T-lymphotropic virus sequences in multiple sclerosis tissue. Nature 322:176-177

6. Iino $T$, Takeuchi $K$, Hyun Nam S, Siomi $H$, Sabe $H$, Kobayashi N, Hatanaka M (1986) Structural analysis of p28 
adult T-cell leukaemia-associated antigen. J Gen Virol 67:1373-1379

7. Karpas A, Kämpf U, Siden A, Koch M, Poser S (1986) Lack of evidence for involvement of known human retroviruses in multiple sclerosis. Nature 322:177-178

8. Koprowski H, DeFreitas EC, Harper ME, Sandberg-Wollheim M, Sheremata WA, Robert-Guroff M, Saxinger CW, Feinberg MB, Wong-Staal F, Gallo RC (1985) Multiple sclerosis and human T-cell lymphotropic retroviruses. Nature 318: $154-160$

9. Kurtzke JF (1983) Rating neurologic impairment in MS: an expanded disability status scale (EDSS). Neurology 33:14441452

10. Maniatis T, Fritsch EF, Sambrook J (1982) Molecular cloning: a laboratory manual. Cold Spring Harbor Laboratory Press, Cold Spring Harbor, NY

11. Myers G (1989) Human retroviruses and AIDS. Los Alamos National Laboratory (USA)

12. Nishimura $M$, Adachi A, Meada M, Akiguchi I, Ishimoto A, Kimura J (1990) Human T lymphotropic virus type I may not be associated with multiple sclerosis in Japan. J Immunol $144: 1684-1688$

13. Ohta M, Ohta K, Mori F, Nishitani H, Saida T (1986) Sera from patients with multiple sclerosis react with human T-cell lymphotropic virus-I gag proteins but not env proteins-Western blotting analysis. J Immunol 137:3440-3443

14. Oldstone MBA, Jensen F, Dixon FJ, Lampert PW (1980) Pathogenesis of the slow disease of the central nervous system associated with wild mouse virus. Virology 107:180-193

15. Pang S, Koyanagi Y, Miles S, Wiley C, Vinters HV, Chen ISY (1990) High levels of unintegrated HIV-1 DNA in brain tissue of AIDS dementia patients. Nature 343:85-89

16. Poser CM, Paty DW, Scheinberg L, McDonald WJ, Davis FA, Ebers EC (1983) New diagnostic criteria for multiple sclerosis: guidelines for research protocols. Ann Neurol 13:227-231

17. Reddy EP (1989) PCR analysis of DNA from multiple sclerosis patients for the presence of HTLV-I. Science 246:823-824

18. Reddy EP, Sandberg-Wollheim M, Mettus RV, Ray PE, De Freitas E, Koprowski H (1989) Amplification and molecular cloning of HTLV-I sequences from DNA of multiple sclerosis patients. Science $243: 529-533$

19. Richardson JH, Wucherpfennig KW, Endo N, Rudge P, Dalgleish AG, Hafler DA (1989) PCR analysis of DNA from multiple sclerosis patients for the presence of HTLV-I. Science 246:821-823

20. Saiki RK, Gelfand DH, Stoffel S, Scharf SJ, Higuchi R, Horn GT, Mullis KB, Erlich HA (1988) Primer directed enzymatic amplification of DNA with a thermostable DNA polymerase. Science 239:487-491

21. Seiki M, Hattori S, Hirayama Y, Yoshida M (1983) Human adult T-cell leukemia virus: complete nucleotide sequence of the provirus genome integrated in leukemia cell DNA. Proc Natl Acad Sci USA 80:3618-3622

22. Shaw GM, Harper ME, Hahn BH, Epstein LG, Gajdusek DC, Price RW, Navia BA, Petito CK, O'Hara CJ, Groopman JE, Cho ES, Oleske JM, Wong-Staal F, Gallo RC (1985) HTLVIII infection in brains of children and adults with AIDS encephalopathy. Science 227:177-182

23. Shimotohno K, Golde DW, Miwa M, Sugimura T, Chen ISY (1984) Nucleotide sequence analysis of the long terminal repeat of human T-cell leukemia virus type II. Proc Natl Acad Sci USA $81: 1079-1083$

24. Sodroski J, Rosen C, Goh WC, Haseltine W (1985) A transcriptional activator protein encoded by the $\mathrm{x}$-lor region of the human $T$ cell leukemia virus. Science $228: 1430-1434$

25. Stowring L, Hasse AT, Petursson G, Georgsson G, Palsson P, Lutley R, Ross R, Szuchet S (1985) Detection of visna virus antigens and RNA in glial cells in foci of demyelination. Virology $141: 311-318$

26. Ter Meulen V, Stephenson JR (1983) The possible role of viral infections in multiple sclerosis and other related demyelinating diseases. In: Hallpike JF, Adams CWM, Tourtellotte WW (eds) Multiple sclerosis. Chapman and Hall, London, pp 241274

27. Yoshida M, Miyoshi I, Hinuma Y (1982) Isolation and characterisation of retrovirus from cell lines of human adult T-cell leukemia and its implication in the disease. Proc Natl Acad Sci USA 79:2031-2035 